\title{
PENGARUH GERAK BEBAS SUDU PADA ROTOR SAVONIUS MODIFIKASI UNTUK TURBIN AIR
}

\author{
${ }^{(1)}$ Budi Hartadi, ${ }^{(2)}$ Rendi \\ ${ }^{(1)(2)}$ Prodi Teknik Mesin Fakultas Teknik, Universitas Islam Kalimantan MAB \\ Jl. Adhiyaksa No. 2 Kayu Tangi, Banjarmasin \\ Email:akbar_mitrajaya@yahoo.com,rendi.teknikmesin@gmail.com
}

\begin{abstract}
ABSTRAK
Turbin air rotor savonius memiliki kinerja yang buruk. Penelitian ini bertujuan untuk Melaksanakan kajian secara eksperimen mencari seberapa beasr pengaruh gerak bebas sudu. Penelitian ini dilaksanakan selama selama 6 bulan yaitu bulan Maret sampai Oktober 2017. Permodelan dilakukan di Laboratorium Teknik Mesin UNISKA dan Pengujian di sungai Pitap desa Tebing Tinggi Kabupaten Balangan Propinsi Kalimantan selatan. Parameter Uji adalah kecepatan putaran roda turbin yang diukur dengan alau ukur Thaco Meter. Variabel uji adakah gerak bebas sudu duiji pada $0^{\circ}, 10^{\circ}, 20^{\circ}$, dan $30^{\circ}$ Analisa hasil eksperimen hanya membandingkan kinerja turbin pada gerakan bebas sudu. Hasil penelitian Gerak bebas sudu berpengaruh terhadap kinerja turbin. Terjadi variasi TSR dan variasi Torsi terhadap penggunaan jarak bebas sudu. Nilai TSR tertinggi pada jarak bebas $0^{\circ}$ sedangkan nilai torsi tertinggi pada jarak bebas sudu $30^{\circ}$. Jumlah sudu berpengaruh terhadap kinerja turbin. Nilai torsi maksimum pada jumlah sudu 3 yaitu $0.38 \mathrm{~N} / \mathrm{m}$. Sedangkan putaran turbin tertinggi pada jumlah sudu 3 yaitu $35,8 \mathrm{rpm}$.
\end{abstract}

Kata Kunci : Eksperimen, Gerak Bebas Sudu, Rotor Savonius

\section{PENDAHULUAN}

Energi merupakan unsur penting dalam pengemangan sosialekonomi dan pertumbuhan ekonomi. Sumber energi terbarukan seperti energi angin, energi air dapat mengurangi ketergantungan pada bahanbakar fosil yang semakin tahun semakin menipis. (Bhatt, H. and Jani, S. 2014)

Energi air dapat dimanfaatkan sebagai pembangkit listrik dengan memanfaatkan tenaga potensial yang tersedia (potensi air terjun dan kecepatan aliran). Indonesia memiliki potensi besar untuk mengembangkan pembangkit listrik tenaga air. Ini disebabkan kondisi topografi Indonesia yang bergunung dan berbukit serta dialiri oleh banyak sungai (besar dan kecil) dan di beberapa daerah tertentu terdapat danau dan atau waduk yang cukup potensial sebagai sumber energi air.

Turbin hidrokinetik adalah salah satu jenis turbin air yang mempunyai prinsif kerja memanfaatkan energi kinetik aliran dari aliran sungai maupun irigasi untuk dijadikan energi mekanik (Verma and Saini, 2015). Turbin ini dikategorikan kedalam jenis turbin rekasi. Ada beberapa jenis turbin hidrokinetik yang dikembangkan dari turbin angin yaitu : jenis rotor Savonius, Jenis rotor darius, Jenis rotor Gorlof dan lainnya.

Turbin hidrokinetik rotor savonius memiliki komonen utama yaitu sudu : biasanya terdiri dari 2 sudu, 3 sudu, 4 sudu dan multi sudu. Beberapa penelitian telah banyak melakukan pengujian dan pengembangan untuk 
meningkatkan performanya. Ada beberapa parameter yang menentukan diantaranya adalah:

1. Rasio Overlap

2. Aspek Rasio

3. Jumlah Sudu dan

4. Tingkatan sudu keunggulan keunggulan dibandingkan dengan turbin-turbin lain, menurut Asroful Anam, (2016) yaitu:

1. Pemilihan lokasi tidak terlalu banyak syarat dan tanpa bendungan

2. Bentuknya sederhana, mudah dibuat dan pemeliharaan mudah,

3. Potensi air yang dibutuhkan hanya aliran air sungai.

Selain keunggulan-keunggulan diatas, turbin rotor Savonius juga memiliki

beberapa kekurangan. Yang pertama, variasi torsi yang cukup besar menyebabkan

getaran pada rotor dan akibatnya menurunkan daya ketahanan (durability) pada rotor. Kemudian yang kedua adalah ada beberapa posisi arah angular yang memiliki torsi statik bernilai negatif atau sangat rendah. Hal ini merupakan suatu kendala ketika rotor Savonius digunakan sebagai starter.

Banyak peneliti melakukan eksperimen dan simulasi pada rotor Savonius. Md. Nahidul Islam Khan (2009) menguji peforma turbin rotor savonius satu tingkat, dua tingkat dan tiga tingkat hasil pengujian bahwa rotor dua tingkat lebih baik. Shouichiro Iio, (2011) dan Kailash Golecha, T.I. (2011) menguji rotor savonius dengan menambahkan pelindung plat didekat rotor hasil pengujian dengan penambahan plat kinerja turbin akan lebih baik. Purnama, Hantoro and Nugroho, (2013) menguji rotor savonius dengan menggunakan pemandu arah aliran. Penelitian dilakukan dengan metode eksperimen Hasil penelitian mengungkapkan bahwa turbin dengan pemandu arah aliran dapat berputar lebih cepat. Rendi (2017) meguji turbin savonius 4 sudu dengan metode simulasi menggunakan software Solid works Flow Simulasi berbasis Finite Elements Analysis (FEA) Method pada kecepatan aliran air sebesar $1,5 \mathrm{~m} / \mathrm{s}$. Hasil penelitian bahwa dengan penambahan deflektor dapat mengurangi tekanan negatif.

Untuk meningkatkan kinerja turbin dan mengurangi tekanan negatif di sisi sudu yang masih terlalu besar maka pada penelitian ini, peneliti akan mencoba mendesain ulang konstruksi sudu turbin supaya sudu turbin bisa bergerak bebas..

\section{METODE PENELITIAN}

Penelitian ini menggunakan metode penelitian eksperimen. Turbin air rotor Savnius dibuat berbahan dasar akrilik dengan tebal $3 \mathrm{~mm}$ dan $2 \mathrm{~mm}$, tinggi sudu dibuat $23 \mathrm{~cm}$, diamter sudu $20 \mathrm{~cm}$, overlap $2.5 \mathrm{~cm}$.

\begin{tabular}{|l|c|c|c|c|}
\multicolumn{5}{|c|}{ Tabel 1. Level Faktor } \\
\cline { 2 - 6 } \multicolumn{1}{|c|}{ Variabel/Faktor } & Level 1 & Level 2 & Level 3 & Level 4 \\
\hline Jumlah Sudu & 2 & 3 & 4 & \\
\hline $\begin{array}{l}\text { Gerak Bebas Sudu } \\
\text { (derajat) }\end{array}$ & 0 & 10 & 20 & 30 \\
\hline Kecepatan Aliran (m/s) & 0,50 & & & \\
\hline
\end{tabular}

Sebelum dilakukan analisa data terlebih dahulu dilakukan perhitungan terhadap parameter-parameter berikut:

1. Tip Speed Ratio (rasio kecepatan ujung) adalah rasio kecepatan ujung rotor terhadap kecepatan aliran air. Tip speed ratio akan berpengaruh pada kecepatan putar rotor.

2. Torsi (T) Torsi adalah gaya putar yang dihasilkan oleh poros turbin atau kemampuan turbin untuk melakukan kerja.

3. Koefesien Torsi

4. Koefesien Daya

5. Efesiensi Mekanis Turbin 


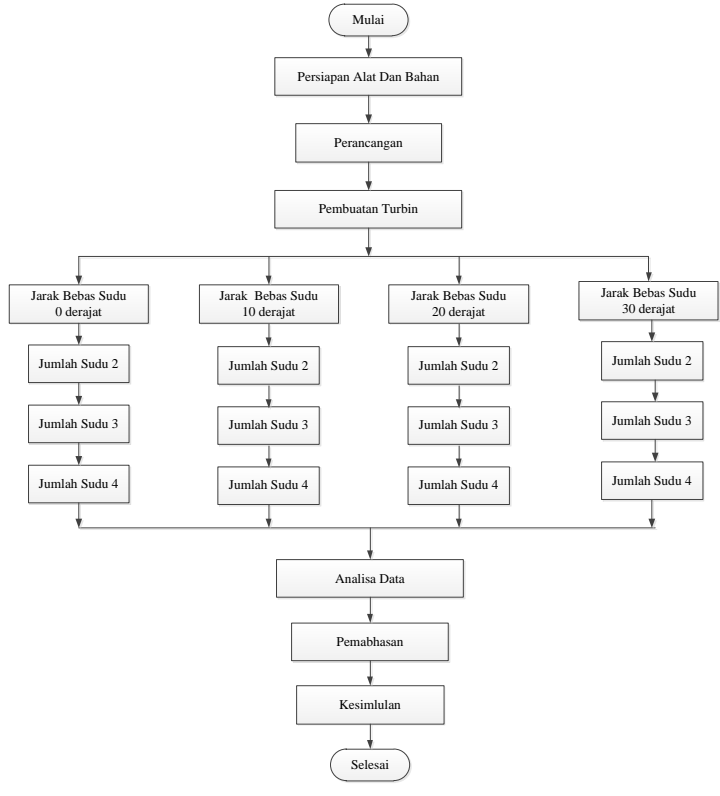

Gambar 1. Diagram Alir Penelitian.

\section{HASIL DAN PEMBAHASAN}

\section{Pengaruh Gerak Bebas Sudu}

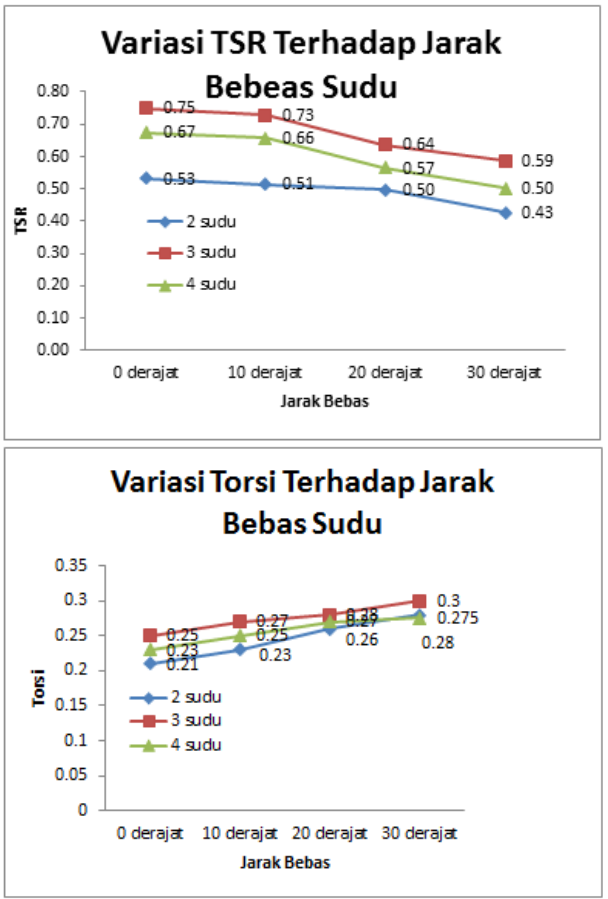

Gambar 2. Variasi (a) RPM terhadap jarak bebas sudu

(b) Torsi terhadap jarak bebeas sudu terjadi variasi TSR dan variasi Torsi terhadap penggunaan jarak bebas sudu. Nilai TSR tertinggi pada jarak bebas 0 derajat yaitu pada sudu 2 sudu 3 dan sudu 4 yaitu 0,53, 0,75 dan 0,67. Sedangkan nilai TSR terendah ditemukan pada jarak bebas 30 derajat yaitu pada sudu 2 sudu 3 dan sudu 4 yaitu $0,47,0,59$ dan 0,50 . Nilai torsi tertinggi ditemukan pada jarak bebas sudu 30 derajt baik pada sudu 2 sudu 3 dan sudu 4 nilai masing-masing adalah $0,245 \mathrm{~N} / \mathrm{m}, 0,28 \mathrm{~N} / \mathrm{m}$ dan $0,3 \mathrm{~N} / \mathrm{m}$ sedangkannilai torsi terendah ditemukan pada jarak bebas 0 derajat pada sudu 2 sudu 3 dan sudu 4.

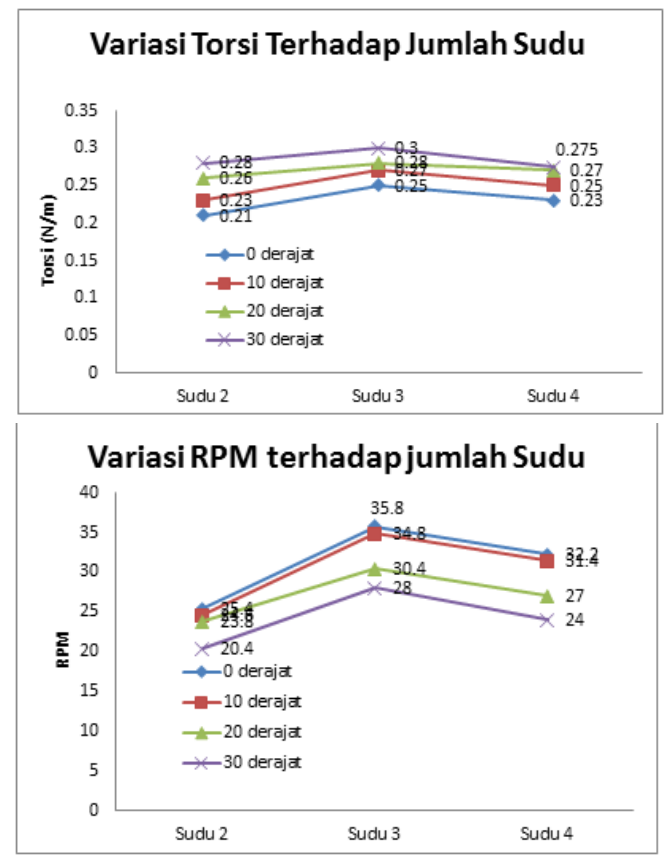

Gambar 4.3. Variasi (a) Nilai torsi terhadap jumlah Sudu

(b) Torsi Terhadap Jumlah Sudu

Nilai torsi maksimum ditemukan pada jumlah sudu 3 yaitu $0.38 \mathrm{~N} / \mathrm{m}$ turbin dengan jarak bebas sudu 30 derajat sedangkan terendah ditemukan pada sudu 2 yaitu $0,2 \mathrm{~N} / \mathrm{m}$ turbin dengan jarak bebas sudu 0 derajat - Sedangkan putaran turbin tertinggi ditemukan pada jumlah sudu 3 yaitu $35,8 \mathrm{rpm}$. Sedangkan terendah ditemukan pada sudu 2 yaitu 20,4 rpm.

\section{KESIMPULAN}

Dari hasil penelitian yang telah dilakukan diperoleh beberapa kesimpulan sebagai berikut:

1. Gerak bebas sudu berpengaruh terhadap kinerja turbin. Terjadi variasi TSR dan variasi Torsi 
terhadap penggunaan jarak bebas sudu. Nilai TSR tertinggi pada jarak bebas 0 derajat yaitu pada sudu 2 sudu 3 dan sudu 4 yaitu $0,53,0,75$ dan 0,67 . Nilai torsi tertinggi pada jarak bebas sudu 30 derajt

Jumlah sudu berpengaruh terhadap kinerja turbin. Nilai torsi maksimum pada jumlah sudu 3 yaitu $0.38 \mathrm{~N} / \mathrm{m}$ turbin dengan jarak bebas sudu 30 derajat sedangkan terendah pada sudu 2 yaitu $0,2 \mathrm{~N} / \mathrm{m}$ turbin dengan jarak bebas sudu 0 derajat . Sedangkan putaran turbin tertinggi pada jumlah sudu 3 yaitu $35,8 \mathrm{rpm}$. Sedangkan terendah pada sudu 2 yaitu 20,4 rpm.

\section{REFERENSI}

[1] Anam, A. 2016. "Pengaruh Variasi Ketinggian Aliran Sungai Terhadap Kinerja Turbin Kinetik Bersudu Mangkok Dengan Sudut Input $10^{\circ}$. Seminar Nasional Inovasi dan Aplikasi Teknologi di Industri (SENATI).2016. Malang. Inonesia. Hal.37-42.

[2] Bhatt, H. and Jani, S. (2014) 'Energy Generation in Water Pipe Lines Savonius Water Turbine Power', International Journal of Research in Advent Technology, 2(12), pp. 23219637

[3] Golecha, K., Eldho, T. I. and Prabhu, S. V. (2011) 'Influence of the deflector plate on the performance of modified Savonius water turbine', Applied Energy, 88(9), pp. 32073217.

doi:

10.1016/j.apenergy.2011.03.025.

[4] Iio, S. et al. (2011) 'Influence of setting condition on characteristics of Savonius hydraulic turbine with a shield plate', Journal of Thermal Science, 20(3), pp. 224-228. doi: 10.1007/s11630-011-0462-9.
[5] Purnama, A. C., Hantoro, R. and Nugroho, G. (2013) 'Rancang Bangun Turbin Air Sungai Poros Vertikal Tipe Savonius dengan Menggunakan Pemandu Arah Aliran', Jurnal Teknik ITS, 2(2), pp. B278-B282.

[6] Rendi.2017 "Analisa Distribusi Tekanan dan Aliran Dusekitar Rotor Savonius Water Turbine" Jurnal Teknik Mesin Uniska Vol 2 No 02 